\title{
Selected Physical Properties and Microscopic Description of Ziziphus mauritiana Lam. Wood in Sudano-Sahelian Region of Nigeria
}

\author{
Josiah Thomas Bitrus Riki ${ }^{12,3 *}$, Olufemi Ashimiyu Sotannde ${ }^{2}$ and Abiodun Oluwafemi Oluwadare \\ ${ }^{1}$ Department of Forestry and Wildlife Management, Faculty of Agriculture and Life Sciences \\ Federal of Wukari, Wukari. Taraba, Nigeria \\ ${ }^{2}$ Department of Forestry and Wildlife, Faculty of Agriculture, University of Maiduguri \\ Borno State Nigeria \\ ${ }^{3}$ Depratment of Forest Production and Products, Faculty of Renewable Natural Resources, University of Ibadan \\ Ibadan, Nigeri \\ *Corresponding author's email: rikijosiah [AT] gmail.com
}

\begin{abstract}
----
Background and Objective:

Wood is a hard, fibrous tissue found in many trees. It has been used for hundreds of thousands of years for fuel, construction and industrial raw materials. Ziziphus mauritiana is a tropical fruit tree species, belonging to the family Rhamnaceae, the specie is abundant in Sudano-sahelion region of Nigeria and it has been reported to have several medicinal uses from the leaves, stem and roots, but technical information on the use of the wood for construction purposes is limited. Therefore, determinations of selected physical and microscopic description of the wood of $Z$. mauritiana as a potential wood material for timber were investigated.
\end{abstract}

Materials and Methods: Three matured trees of Z. mauritiana were felled from a research plantation of the Department of Forestry and Wildlife within the University of Maiduguri, in the North-eastern part of Nigeria and cross-cut into billets at the base, middle and top of the stems with estimated ages of 7, 6 and 6 years old accordingly from the three sampled trees. Discs were obtained from each billet for determination of Physical properties (Bark, Bast, Sapwood, heartwood and pith proportion, Moisture content (MC), Density and some microscopic description (fibre and parenchyma cells) were all determined.

Results: The average wood density of the sampled trees stood at $0.55 \pm 0.01 \mathrm{~g} / \mathrm{cm}^{3}$ and decreased from base to top. Similarly, moisture content decreased from $75.66 \pm 3.83 \%$ at the base to $54.08 \pm 1.19 \%$ at the top of the sampling height. The volumetric shrinkage is the total shrinkage in wood volume and it amounted to $10.11 \pm 3.17 \%$. Averagely, bast accounted for $3.56 \pm 0.70 \%, 6.50 \pm 0.89 \%, 69.38 \pm 0.50 \%, 16.00 \pm 3.23 \%$ and $10.38 \pm 1.96 \%$ for bark, sapwood, heartwood and pith proportions respectively across the stem. Abundant fibres and parachyma cells were observed on the microscopic examination.

Conclusion: The wood of Z. mauritiana is heavy. Within tree, wood density decreased from the base to the top. The range of values obtained in this study fall within the range of $450-750 \mathrm{~kg} / \mathrm{m}^{-3}$ for species suitable for furniture, sheeting and lining, parquet, veneer wood for peeling and slicing with abundant fibres and parenchyma cells. The range of values of volumetric shrinkage along the height and radial position shows that the wood is dimensionally stable. This was evident in the low tangential-radial shrinkage ratios recorded. Thus, indicating a low risk of deformation in wood during seasoning.

Keyword---- Physical, Anisotropic Shrinkage, Microscopy

\section{INTRODUCTION}

Wood is a complex material attractive to many users because of its versatility. It is a preferable structural material used for construction purposes especially due to the natural durability, physical and strength properties. Physical properties are the quantitative characteristics of wood and its behaviour to external influences other than applied forces. Familiarity with physical properties is important because they can significantly influence the performance and strength of wood used in structural applications ${ }^{1,2}$. Phillips ${ }^{3}$, stressed the fact that physical properties such as wood density affects the technical performance of wood, its use and in particular the strength and processing behavior of sawn wood. 
Ziziphus mauritiana Lam. belongs to the family of Rhamnaceace. It is a tropical fruit tree species. It is a spiny, evergreen shrub or small tree up to $15 \mathrm{~m}$ high, with trunk $40 \mathrm{~cm}$ or more in diameter; spreading crown; stipular spines and many drooping branches. The plant is a shrub between four to six $\mathrm{ft}(1.2-1.8 \mathrm{~m})$ high or a tree 10 or even $40 \mathrm{ft}$ (3-9 or $12 \mathrm{~m})$ tall. Originally native to India it is now widely naturalized in tropical region in tropical region in Africa ${ }^{4}$.

The rapid and steady increase in demand of high quality timber in the Sudano-sahelian region and Nigeria as a whole has resulted in over exploitation of very strong and durable species as a result of population increase, there now have been a problem of scarcity rise in price of wood product and technical information on these species is lacking to enhance its success and acceptability in the timber market for structural and construction works. This study was conducted to determine the physical properties of Z. mauritiana in Sudano-Sahelian region of Borno State, Nigeria to serve as substitute for the scarcity of economical wood species for construction and structural purposes.

\section{Study Area}

\section{MATERIALS AND METHODS}

Three trees of $Z$. mauritiana used for this study was felled from a research plantation of the Department of Forestry and Wildlife within the University of Maiduguri, in the north-eastern part of Nigeria, located on latitude $11^{\circ} 30^{\prime \prime} \mathrm{N}$ and longitude $14^{\circ} 45^{\prime} \mathrm{E}$. The climate is hot and dry for most part of the year. The average annual rainfall is $650 \mathrm{~mm}$ with a relative humidity of $42-49 \%$. The soil type is generally sandy loam and well drained ${ }^{5}$.

From each bole, 3 discs of $5 \mathrm{~cm}$ height and a billet of $30 \mathrm{~cm}$ were cut from each bole making a total of 9 discs and 3 billets from each stem, and 27 discs and 9 billets from the three stems. From the 27 discs obtained, the following measurements were carried out.

\section{Sampling Technique}

Three trees of fairly straight and cylindrical bole with no sign of mechanical damage or attack by fungi and insects were randomly selected from the plantation. The sampled trees were felled approximately $15 \mathrm{~cm}$ to the ground and neatly debranched. From each tree, 3 discs of $6 \mathrm{~cm}$ height and a billet of $30 \mathrm{~cm}$ were cut from each bole making a total of 3 discs from each stem and 9 discs were taken at three height levels: base, middle and top of the merchantable height (MH).

\section{Determination of Bark thickness}

To obtain the bark thickness of each sampled disc, calibrated ruler was placed on the transverse surface of the disc to measure diameter outside bark of the disc and diameter inside bark which is the xylem (wood). The bark thickness was obtained using the following formula:

$\mathrm{BT}=\mathrm{DOB}-\mathrm{DIB}$ Eqn.1

Where:

BT is the bark thickness,

DIB is diameter inside bark (wood),

DOB is diameter outside bark.

\section{Determination of Sap and Heart wood}

There is a visual distinction from sapwood, heartwood to the Pith. The pith is located at the centre of the wood which is darker in colour and well distinct. The heartwood is brownish or yellowish in colour that distinguished from the light colour of sapwood portion.

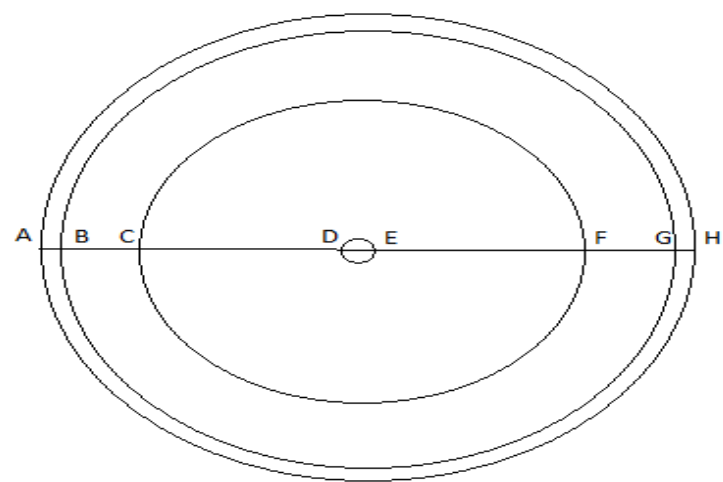

Fig 1: Annotated diagram of a wood cross section $\mathrm{AB}$ and $\mathrm{GH}$ represent the bark; $\mathrm{BC}$ and FG represent the sapwood; $\mathrm{CD}$ and EF represent the heartwood; DE represents the pith. 


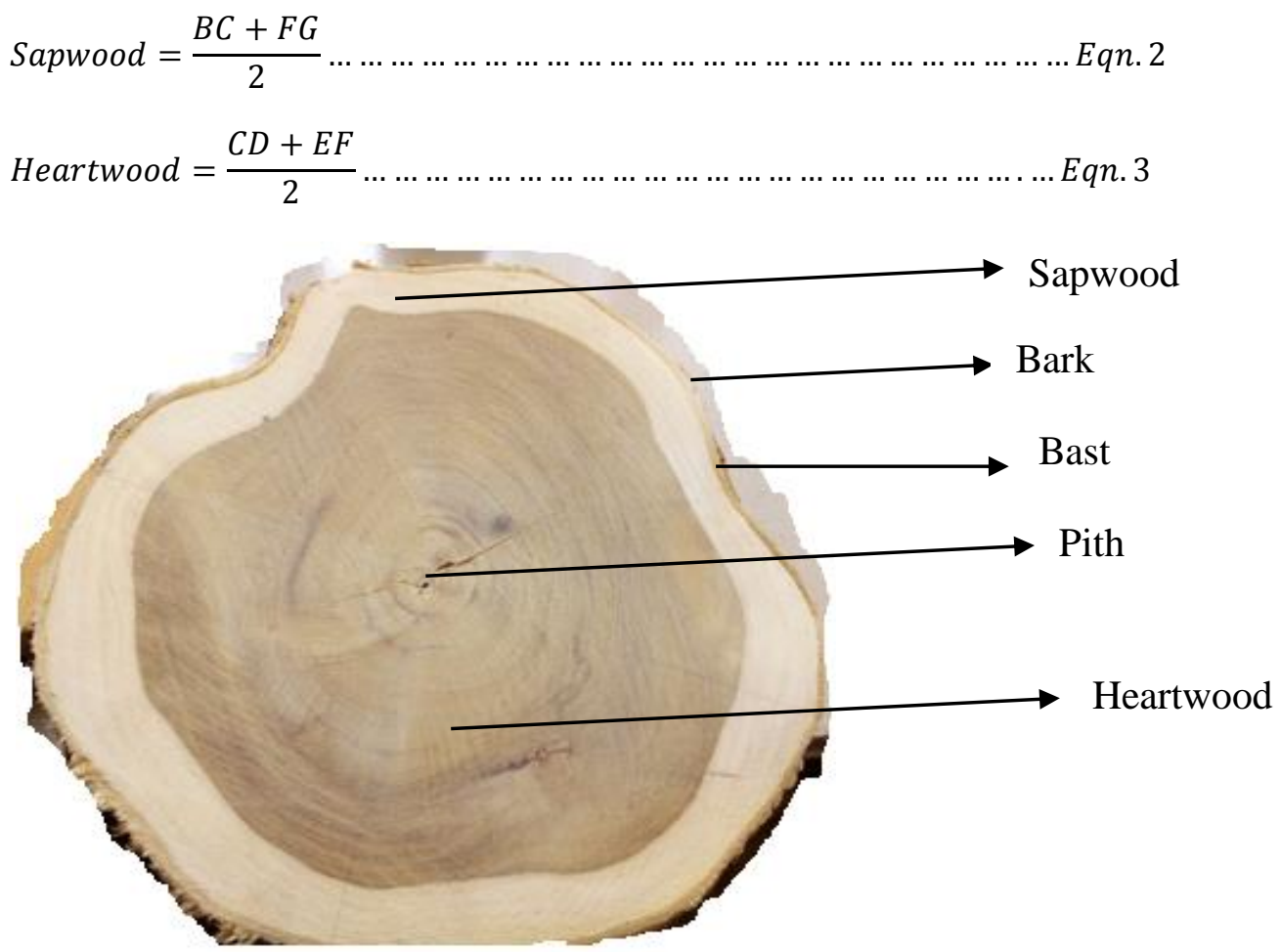

Plate 1: Annotated diagram of a stem cross section of Z. mauritiana

\section{Determination of Wood Density}

The freshly cut sample of $2 \mathrm{~cm} \times 2 \mathrm{~cm} \times 2 \mathrm{~cm}$ of about 90 cubes were weighed each with an electronic weighing balance while the volume of each sample were computed based on their dimension. The samples were oven-dried at a temperature of $102 \pm 3{ }^{\circ} \mathrm{C}$ and weighed at an interval until a constant weight was obtained. Thereafter, the oven dried weight was measured together with the dimension of each cube. Density was then determined using this relationship: $P=W_{0}$ Eqn. 8

$V_{0}$

Where;

$P=$ density $\left(\right.$ g.cm- $\left.{ }^{3}\right)$

$\mathrm{W}_{0}=$ oven-dry weight $(\mathrm{g})$

$\mathrm{V}_{0}=$ volume $\left(\mathrm{cm}^{3}\right)$

\section{Determination of Moisture Content of Wood}

The test wood samples of $2 \mathrm{~cm} \times 2 \mathrm{~cm} \times 2 \mathrm{~cm}$ were weighed with an electronic weighing balance. The initial weight was recorded and the test wood samples were placed in the oven at $102^{\circ} \mathrm{C} \pm 3$ cooled in a desiccator containing silica gel and weighed at an interval until a constant weight was obtained. The moisture content was calculated according with ASTMD $4442-84^{6}$ using the equation:

$M C=\frac{W m-W o}{W o} \times 100$. Eqn. 9

Where:

$\mathrm{MC}=$ Moisture Content

$\mathrm{Wm}=$ Weight of the test wood samples before oven-drying $(\mathrm{g})$

$\mathrm{Wo}=$ Weight of the test wood samples after oven-drying $(\mathrm{g})$

\section{Anisotropic Characteristics of Wood}

It has been established that the shrinkage of wood from green to air dried condition in axial or longitudinal direction is normally small, thus only the shrinkage from maximum moisture content (M.M.C.) to oven-dry moisture content was considered. Samples were soaked in water for 48 hours and their dimensions were taken at M.M.C. in the longitudinal, radial and tangential surfaces. The samples were then oven-dried at temperature of $102 \pm 3^{\circ} \mathrm{C}$ for 48 hours until the weights of the samples remained constant. The dimensions of the oven-dried samples were again taken at the same spots as when they were taken at M.M.C. Shrinkage was calculated for the longitudinal, radial and tangential surfaces based on measured dimensions at soaked and oven-dry conditions. The dimensional shrinkage in longitudinal, radial and tangential directions will be obtained through the formulae as shown below based on the method adopted by Sotannde el al., 7 . 
$\operatorname{Tg} s=D t-d t \times 100$ ..Eqn. 4

$d t 1$

$R g s=D r-d r \times 100$. .Eqn. 5

$d r 1$

$L g s=D l-d l \times 100$ Eqn. 6

dl 1

Where:

Tgs = Tangential shrinkage

Rds $=$ Radial shrinkage

Lgs = Longitudinal shrinkage

$\mathrm{Dt}=$ Tangential dimension $(\mathrm{mm})$ at $\mathrm{MMC}$

$\mathrm{Dr}=$ Radial dimension $(\mathrm{mm})$ at $\mathrm{MMC}$

$\mathrm{Dl}=$ Longitudinal dimension $(\mathrm{mm})$ at $\mathrm{MMC}$

$\mathrm{dt}=$ Tangential dimension $(\mathrm{mm})$ at oven-dry at MMC

$\mathrm{dr}=$ Radial dimension $(\mathrm{mm})$ at oven-dry MMC

$\mathrm{dl}=$ Longitudinal dimension $(\mathrm{mm})$ at oven-dry MMC

The volumetric shrinkage (VS) of each sample was computed using the relationship below:

VS $=100-\frac{(100-\text { Lgs })(100-\text { Rds })(100-\text { Tgs }) \%}{10^{4}}$

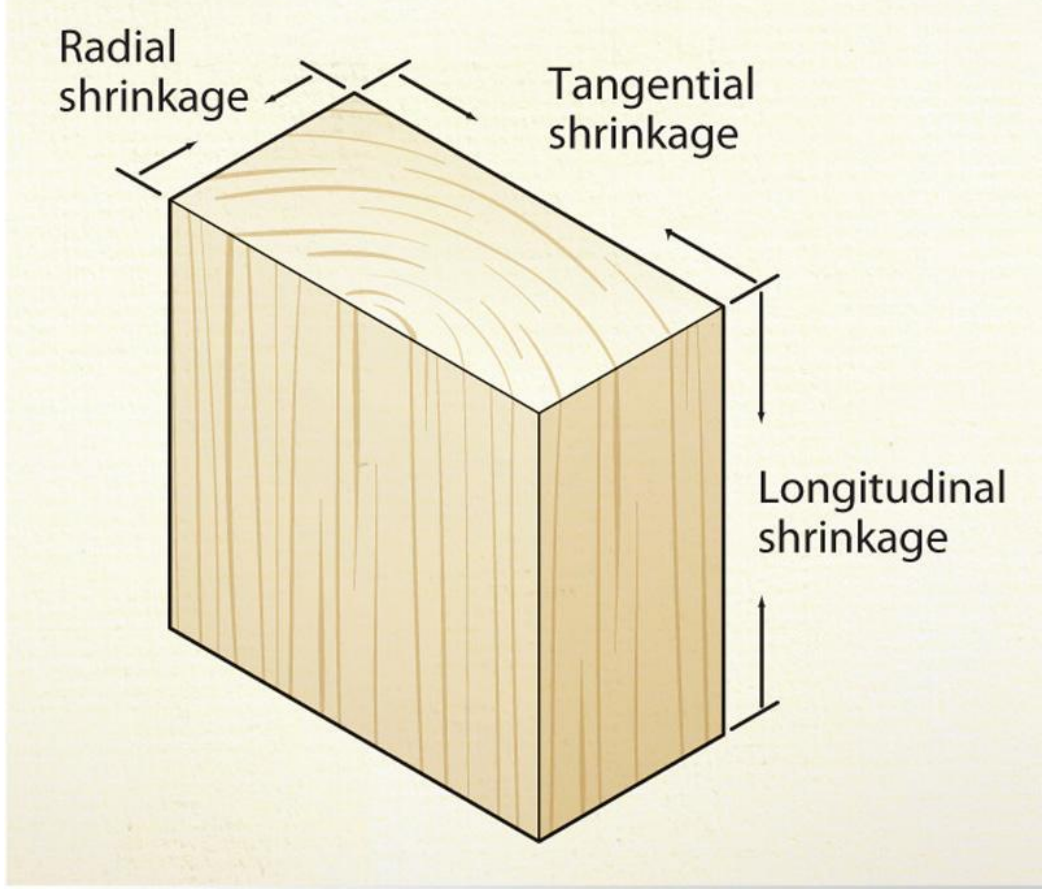

Figure 2: Anisotropic properties of wood $^{8}$.

\section{Determination of wood samples for Micrographic Description}

To prepare the stem discs for microscopic description, samples were cut into blocks of $2 \times 2 \times 2 \mathrm{~cm}$ for easy clamping on microtome holders and carefully labeled for easy identification. The wooden blocks were soaked in water for 17-24 $\mathrm{h}$ to soften for easy sectioning based on the density of the wood. The wood blocks were oriented to show the Radial longitudinal sections. The sections were $0.02 \mathrm{~mm}$ thick wood in size. However, the steps taken in slides preparation were:

$>$ Sections were stained with safranin $\mathrm{O}$ for $30 \mathrm{~min}$ and then rinsed in water. The sections were immersed in 50 and $95 \%$ ethanol. The ethanol was used to extract the excess staining on the sections.

$>$ Ethanol solvent was cleared by covering the sections with several drops of clove oil for about 5 min.

$>$ Sections were transferred into xylene. The process of immersing into xylene solvent is called dehydration and differentiation process.

$>$ Sections were mounted on the slides with the use of Canada balsam. The function of the Canada balsam is to help place the cells intact, without shrinking or collapsing for a very long period and to be seen clearly. Descriptive terminology and measurements described by Quilho et al., ${ }^{9}$. 
Lastly, sample representative was selected and examined under the microscope in order to view the fibre and parenchyma cells along the dimensional plains and the photomicrographs for fibres and parenchyma cells were taken.

\section{Bast Proportion (\%)}

\section{RESULTS}

The bast proportion followed the same pattern as it increased from the base to top as it was observed to constitute a substantial part of the bark in the sampled. Table 1 shows bast proportion has no significant difference among the sample species except along the sampling height $(\mathrm{P}<0.05)$. They increased from $2.16 \pm 1.02 \%$ at base to $5.01 \pm 0.12 \%$ at the top Averagely, bark accounted for $3.56 \pm 0.70 \%$ of the stem cross section (Table 2). Among the sampled trees, TN3 had the highest bark proportion with average value of $4.22 \pm 0.01 \%$ while TN2 had the least average value of $3.91 \pm 0.90 \%$ (Table 2).

\section{Bark Proportion}

The bark proportion does not show significant difference among the tree samples $(\mathrm{P}<0.05)$ as presented in Table 1 . The averagely bark proportion decreased from $7.07 \pm 0.24 \%$ at base to $5.71 \pm 0.61 \%$ at the top. Averagely bark accounted for $6.50 \pm 0.89 \%$ of the stem cross section (Table 2). Among the tree samples, TN3 has the highest bark proportion while TN2 had the least (Table 2).

\section{Sapwood Proportion}

There is significant difference in sapwood proportion along the sampling height of tree samples $(\mathrm{P}<0.05)$ and not significant among tree samples $(\mathrm{P}>0.05)$ as shown in Table 1 . The sapwood proportion increased from the base to the top with values of $57.01 \pm 1.15$,

$71.08 \pm 0.11$ and $80.05 \pm 0.23 \%$ obtained at the base, middle and top of the sampled stems respectively. Overall, sapwood accounted for $69.38 \pm 0.50 \%$ of the stem (Table 2). Among trees, TN3 had the widest sapwood proportion $(64.01 \pm 0.33 \%)$ while TN1 had the least $(59.07 \pm 0.99 \%)$ (Table 2).

\section{Heartwood proportion}

The heartwood proportion varies considerably among the sample trees and along the sampling height $(\mathrm{P}<0.05)$ as presented in Table 1. The averagely bark proportion decreased from $28.04 \pm 4.95 \%$ at base to $5.31 \pm 3.11 \%$ at the top. Averagely bark accounted for $16.00 \pm 3.23 \%$ of the stem cross section (Table 2). Among the tree samples, TN3 has the highest bark proportion of $30.01 \pm 3.45$ while TN1 had the least with $17.03 \pm 0.12 \%$ (Table 2).

\section{Pith proportion}

The pith proportion also increased from the base of the stem to the top with average values of $8.21 \pm 1.27 \%$ obtained at the base and $11.92 \pm 0.88 \%$ at the top of the stem height. Averagely, pith proportion accounted for $10.38 \pm 1.96 \%$ of the total stem (Table 2). Meanwhile, among trees, TN1 had the largest pith proportion with mean value of $12.34 \pm 81 \%$ while TN2 had the least, $7.22 \pm 1.12 \%$ (Table 2). There is marked effect among the species and sampling heights $(\mathrm{P}<0.05)$ as shown in Table 1.

Table 1: Anova results of the variations in Wood Properties of the sampled trees

\begin{tabular}{lllllll}
\hline Sources of Variations & Df & BSTP & BKP & SWP & HWP & PTP \\
\hline Tree Number $(\mathrm{TN})$ & 2 & $7.57 \mathrm{~ns}$ & $9.14 \mathrm{~ns}$ & $33.12 \mathrm{~ns}$ & $24.34^{*}$ & $11.59^{*}$ \\
Sampling Height $(\mathrm{SH})$ & 2 & $114.80^{*}$ & $1.50 \mathrm{~ns}$ & $2.00^{*}$ & $9.40^{*}$ & $11.21^{*}$ \\
TNXSH & 4 & $3.12^{*}$ & $5.17 \mathrm{~ns}$ & $17.42^{*}$ & $71.23^{*}$ & $47.89^{*}$ \\
Error & 41 & 0.51 & 7.10 & 0.33 & 4.23 & 2.99 \\
Total & 49 & & & & & \\
\hline
\end{tabular}

* = significant $(\mathrm{P}<0.05), \mathrm{ns}=$ not significant $(\mathrm{P} \geq 0.05), \mathrm{Df}=$ Degree of freedom.

Table 2: Variation in Wood Properties of the sampled trees

\begin{tabular}{llllll}
\hline Tree Sample & BSTP\% & BKP\% & SWP\% & HWP\% & PTP\% \\
\hline
\end{tabular}




\begin{tabular}{llllll}
\hline TN1 & $4.03 \pm 0.41 \mathrm{a}$ & $7.01 \pm 0.01 \mathrm{a}$ & $59.07 \pm 0.99 \mathrm{a}$ & $17.03 \pm 0.12 \mathrm{a}$ & $12.34 \pm 81 \mathrm{a}$ \\
TN2 & $3.91 \pm 0.90 \mathrm{a}$ & $6.79 \pm 0.08 \mathrm{a}$ & $61.02 \pm 0.16 \mathrm{a}$ & $21.91 \pm 1.23 \mathrm{~b}$ & $7.22 \pm 1.12 \mathrm{c}$ \\
TN3 & $4.22 \pm 0.01 \mathrm{a}$ & $6.23 \pm 0.90 \mathrm{a}$ & $64.01 \pm 0.33 \mathrm{a}$ & $30.01 \pm 3.45$ & $11.98 \pm 9.99 \mathrm{ab}$ \\
Sampling Height & & & & & \\
& & & & & \\
Base & $2.16 \pm 1.02 \mathrm{a}$ & $7.07 \pm 0.24 \mathrm{a}$ & $57.01 \pm 1.15 \mathrm{a}$ & $28.04 \pm 4.95 \mathrm{a}$ & $8.21 \pm 1.27 \mathrm{a}$ \\
Middle & $3.50 \pm 0.95 \mathrm{~b}$ & $6.72 \pm 1.13 \mathrm{a}$ & $71.08 \pm 0.11 \mathrm{~b}$ & $14.64 \pm 2.10 \mathrm{~b}$ & $11.03 \pm 1.29 \mathrm{~b}$ \\
Top & $5.01 \pm 0.12 \mathrm{c}$ & $5.71 \pm 0.61 \mathrm{a}$ & $80.05 \pm 0.23 \mathrm{c}$ & $5.31 \pm 3.11 \mathrm{c}$ & $11.92 \pm 0.88 \mathrm{bc}$ \\
Pooled Mean & $3.56 \pm 0.70$ & $6.50 \pm 0.89$ & $69.38 \pm 0.50$ & $16.00 \pm 3.23$ & $10.38 \pm 1.96$ \\
\hline
\end{tabular}

*Means \pm Standard error of 3 replicate samples.

Note: $\mathrm{BKP}=$ Bark proportion, $\mathrm{BSTP}=$ Bast proportion, $\mathrm{SWP}=$ sapwood proportion, $\mathrm{HWP}=$ Heartwood proportion, $\mathrm{PTP}$ $=$ Pith proportion.

Wood Density

The average wood density of the sampled trees stood at $0.55 \pm 0.01 \mathrm{~g} / \mathrm{cm}^{3}$. Within tree, it decreased from $0.60 \pm 0.01 \mathrm{~g} / \mathrm{cm} 3$ at the base to $0.48 \pm 0.01 \mathrm{~g} / \mathrm{cm} 3$ at the top (Table 4). Among the sampled trees, TN1 had the highest density averaged $0.767 \pm 0.23 \mathrm{~g} / \mathrm{cm}^{3}$ while TN1 had the least density $(0.63 \pm 0.11 \mathrm{~g} / \mathrm{cm} 3)$ (Table 3$)$. Table 3 show that there is significant difference in the sampling height at $(\mathrm{P}<0.05)$. Density varied only along the sampling heights.

\section{Moisture Content}

Table 3 shows a mark effect along sampling height of the sample trees $(\mathrm{P}<0.05)$ and does not vary among trees $(\mathrm{P}>0.05)$. Moisture content accounted for $66.40 \%$ of the oven dried wood samples. It follow same pattern as that of density as it decreased from $75.66 \pm 3.83 \%$ at the base to $54.08 \pm 1.19 \%$ at the top of the sampling height (Table 4). Among the trees, TN1 had the highest moisture content of $75.66 \pm 3.83 \%$ while TN3 had the least moisture content of $69 \pm 1.19 \%$ (Table 4).

Table 3: Anova results of Wood Density and Moisture content along Sampling Height

\begin{tabular}{llll}
\hline Sources of variation & Df & Density & \multicolumn{1}{c}{ Moisture Content } \\
\hline Tree Number $(\mathrm{TN})$ & 2 & $0.10^{\mathrm{ns}}$ & $287.62^{\mathrm{ns}}$ \\
Sampling height $(\mathrm{SH})$ & 2 & $0.01^{*}$ & $370.19^{*}$ \\
TN x SH & 4 & $1.23 \mathrm{~ns}$ & $24.14^{*}$ \\
Error & 41 & 6.66 & 7.67 \\
Total & 49 & & \\
\hline
\end{tabular}

* = Significant $(\mathrm{P}<0.05), \mathrm{ns}=$ not significant $(\mathrm{P} \geq 0.05), \mathrm{df}=$ Degree of freedom

Table 4: Variation in Wood Properties of the sampled trees along Sampling Height

\begin{tabular}{|c|c|c|}
\hline Tree Sample & Density $\left(\mathrm{g} / \mathrm{cm}^{3}\right)$ & Moisture Content (\%) \\
\hline TN1 & $0.63 \pm 0.11$ & $75.66 \pm 3.83$ \\
\hline TN2 & $0.62 \pm 0.02$ & $70.46 \pm 2.63$ \\
\hline TN3 & $0.61 \pm 0.01$ & $69 \pm 1.19$ \\
\hline \multicolumn{3}{|c|}{ Sampling Height } \\
\hline Base & $0.60 \pm 0.01 \mathrm{a}$ & $75.66 \pm 3.83 \mathrm{a}$ \\
\hline Middle & $0.58 \pm 0.0 \mathrm{ab}$ & $69.46 \pm 2.63 \mathrm{ab}$ \\
\hline Top & $0.48 \pm 0.0 \mathrm{c}$ & $54.08 \pm 1.19 \mathrm{c}$ \\
\hline Mean & $0.55 \pm 0.01$ & $66.40 \pm 9.92$ \\
\hline
\end{tabular}

\footnotetext{
* Means \pm Standard error of mean of 3 replicate samples while, values with the same alphabet on the same column and same section are not significantly different at $=0.05$.
}

\section{Longitudinal shrinkage}

\section{ANISOTROPIC CHARACTERISTICS OF WOOD}

Longitudinally, the shrinkage increased from $0.42 \pm 0.40 \%$ at the base to $0.53 \pm 0.37 \%$ at the top of the sampled stem. Overall, shrinkage in longitudinal direction accounted for $0.64 \%$ of the volumetric shrinkage of the wood samples (Table $6)$. Among the Trees, TN3 had the highest longitudinal shrinkage averaged $0.81 \pm 0.91 \%$ while TN2 had the least averaged $0.51 \pm 0.67 \%$ (Table 6).

\section{Radial shrinkage}

Radially, shrinkage accounted for $3.15 \%$ of the total shrinkage of the wood. The variation of the radial shrinkage follows a regular pattern as decreased from $3.67 \pm 1.07 \%$ at the base to $2.57 \pm 0.87 \%$ at the top of the stem height. Among the trees, TN2 had the highest radial shrinkage with average value of $3.56 \pm 0.11 \%$ while TN3 had the least with $2.91 \pm 2.78 \%$ (Table 6). There is no any significant difference both within and between the trees (Table 5).

\section{Tangential shrinkage}


As noted in longitudinal shrinkage, tangential shrinkage also increased from the base with average value of $6.96 \pm 1.87 \%$ to $7.66 \pm 3.49 \%$ at the middle but later decreased to $5.31 \pm 1.02 \%$ at the top of the stem height. Averagely the tangential shrinkage accounted for $6.64 \pm 2.30 \%$ of the total volumetric shrinkage (Table 6). Among the tree samples, TN3 had the highest tangential shrinkage of $7.83 \pm 0.99 \%$ while TN2 had the least $(2.12 \pm 0.33 \%)$ (Table 6). There are no considerable variation within and between the wood specie for the tangential shrinkage.

\section{Volumetric shrinkage}

The volumetric shrinkage is the total shrinkage in wood volume and it amounted to $10.11 \pm 3.17 \%$ of the stem wood volume. It increased from $10.73 \pm 3.12 \%$ at the base to $11.37 \pm 4.45 \%$ at the middle and later decreased to $8.23 \pm 1.60 \%$ at top of the stem height (Table 6). Among trees, TN3 had the highest volumetric shrinkage of $11.93 \pm 0.11 \%$ while TN1 had the least value of $7.12 \pm 0.12 \%$ (Table 6). Also, there is a significant difference between the sampled trees $(\mathrm{P}<0.05)$ and no noticeable difference within the sampled trees (Table 5).

Table 5: Anova Results of Shrinkage Properties of the sampled Trees along Sampling Height

\begin{tabular}{llllll}
\hline Sources of variations & Df & Lgs & Rds & Tgs & VS \\
\hline Tree Number (TN) & 2 & $0.17^{*}$ & $0.52 \mathrm{~ns}$ & $0.72^{*}$ & $0.81^{*}$ \\
Sampling height $(\mathrm{SH})$ & 2 & $1.22 \mathrm{~ns}$ & $0.92 \mathrm{~ns}$ & $4.38 \mathrm{~ns}$ & $8.25 \mathrm{~ns}$ \\
TN X SH & 4 & $0.61 \mathrm{~ns}$ & $1.43 \mathrm{~ns}$ & $3.22^{*}$ & $2.87 \mathrm{~ns}$ \\
Error & 41 & 0.13 & 0.95 & 5.58 & 10.68 \\
Total & 49 & & & & \\
\hline
\end{tabular}

$*$ Significant $(\mathrm{P}<0.05), \mathrm{ns}=$ not significant $(\mathrm{P} \geq 0.05), \mathrm{df}=$ Degree of freedom

Table 6: Variation in Shrinkage Properties of the sampled Trees along Sampling Height

\begin{tabular}{|c|c|c|c|c|}
\hline Tree Sample & Lgs & Rds & Tgs & Vs \\
\hline TN1 & $0.68 \pm 0.11 b$ & $3.21 \pm 0.13 \mathrm{a}$ & $4.99 \pm 0.24 b$ & $7.12 \pm 0.12 b c$ \\
\hline TN2 & $0.51 \pm 0.67 \mathrm{bc}$ & $3.56 \pm 0.11 \mathrm{a}$ & $2.12 \pm 0.33 \mathrm{c}$ & $11.93 \pm 0.11 \mathrm{a}$ \\
\hline TN3 & $0.81 \pm 0.91 \mathrm{a}$ & $2.91 \pm 2.78 \mathrm{a}$ & $7.83 \pm 0.99 a$ & $8.87 \pm 12.13 b$ \\
\hline \multicolumn{5}{|l|}{ Sampling Height } \\
\hline Base & $0.42 \pm 0.40 \mathrm{a}$ & $3.67 \pm 1.07 \mathrm{a}$ & $6.96 \pm 1.87 \mathrm{a}$ & $10.73 \pm 3.12$ \\
\hline Middle & $0.87 \pm 0.31 \mathrm{a}$ & $3.22 \pm 1.00 \mathrm{a}$ & $7.66 \pm 3.49 \mathrm{a}$ & $11.37 \pm 4.45$ \\
\hline Top & $0.53 \pm 0.37 \mathrm{a}$ & $2.57 \pm 0.87 \mathrm{a}$ & $5.31 \pm 1.02 b$ & $8.23 \pm 1.60$ \\
\hline Mean & $0.61 \pm 0.37$ & $3.15 \pm 0.98$ & $6.64 \pm 2.30$ & $10.11 \pm 3.17$ \\
\hline
\end{tabular}

* Means \pm Standard error of mean of 3 replicate samples while, values with the same alphabet on the same column and same section are not significantly different at $=0.05$.

\section{Microscopic Description of $Z$. mauritiana}

As shown in the photomicrograph of Z. mauritiana wood, the wood possessed characteristics indicating that of the sudanosahelian woods with dense fibres and parenchyma cells present in the hardwoods. The Parenchyma cells are abundant, diffuse in aggregate, confluent with continuous and discontinuous bands.

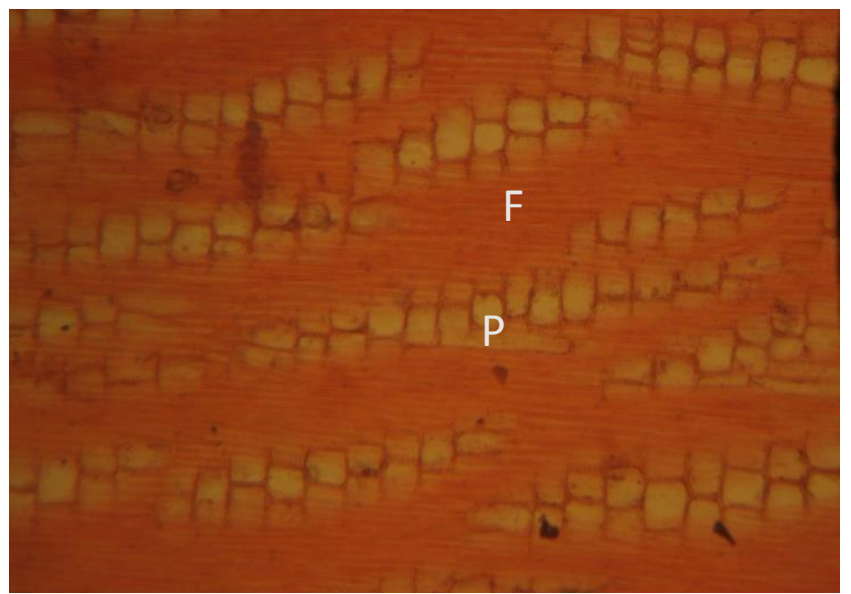

Plate 1: Radial Longitudinal section showing F: Fibre, P: Parenchyma (x 100). 


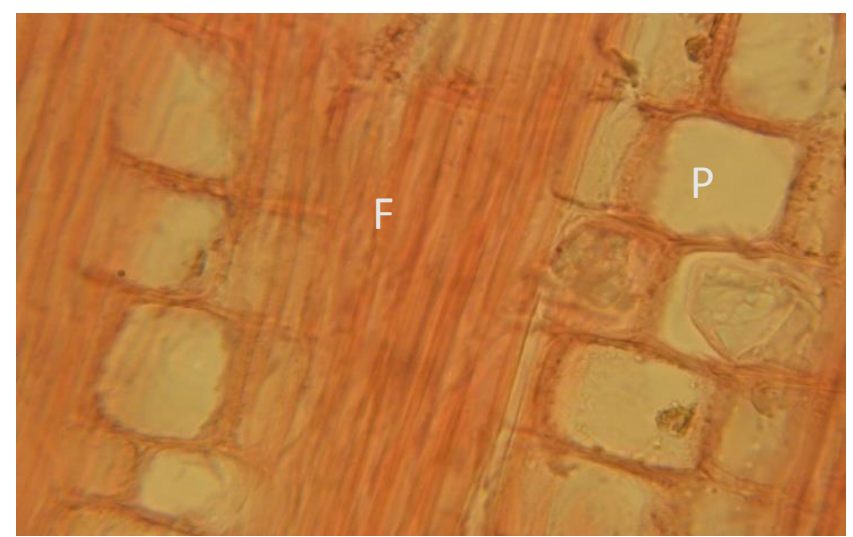

Plate 2: Radial Longitudinal section showing F: Fibre, P: Parenchyma (x 400).

\section{DISCUSSION}

\section{Bast Proportion (\%)}

The bast is an additional source of fibre. Depending on the quality of the fibre, it could furnish additional fibre material in addition to the woody portion, this need further investigation because the total bast might be an indication of relative growth rate of the tree. Since bast is made of mostly cambium cell. Bast fibre, could furnish additional fibre material in addition to the woody portion ${ }^{10,5}$.

\section{Bark Proportion}

The bark protects the wood from extreme temperature, drought, provides mechanical protection to the softer inner bark and also help to limit evaporative water loss (Sotannde et al., ${ }^{11}$ It is rich in chemical substances such as tannin and dyes derived plant metabolism. In all the sampled trees bark thickness decreases from the base to the top. The same pattern of variation was reported by Sotannde and $\mathrm{Riki}^{5}$ in some wood species in the region and average value of $6.50 \pm 0.89 \%$ accounted for the stem cross section. This perhaps explains the juvenility of the sampled trees. Being dry zone species it is expected that the bark values could be higher as an adaptive feature of the species to cope with water stress and high temperature.

\section{Sapwood Proportion}

The increase from the base to the top in sapwood proportion as observed in this specie was also reported by Sotannde $e t$ al., ${ }^{11}$ and Sotannde and $\mathrm{Riki}^{5}$, in some wood species in same region.

The outer portion of a wood stems, trunk or log usually distinguishable from the core or heartwood by its lighter colour is called the sapwood. In the living tree, the sapwood is responsible not only for the conduction of sap, but also for the storage and synthesis of biochemicals. Starch grains are stored in the parenchyma cells, and can be easily seen using a microscope. The starch content of sapwood can have important ramifications in the wood industry ${ }^{12}$. To wood workers, the most significant aspect of sapwood is the colour which ranges from whitish to yellowish or light ${ }^{13,5}$.

\section{Heartwood proportion}

This is the inner portion of the wood where food begins to break down into compound known as extractive or an area of wood where colored extractives are present Taylor and Cooper ${ }^{14}$.

Along the sampling height there is a general reduction in heartwood proportion from the

base to the top with the whole averaged of the samples decreases from the base to top. Though heartwood exerts little or no influenced on both strength and physical properties ${ }^{3,11}$. It is believed to enhance the durability of stress due to presences of extractive content.

\section{Pith proportion}

The pith proportion increases from the base to the top along the sampling height in all the samples with averaged $8.21 \pm 1.27 \%$ at the base $11.03 \pm 1.29 \%$ at the middle and $11.92 \pm 0.88 \%$ at the top. This shows that more mature wood at the base had lower proportion of pith and juvenile wood at the top had greater proportion.

Pith is the central core of the wood. It is formed by epical meristem of the growing tip which is found in the stems and sometimes in the root. The shape and diameter help in the identification of plant species producing the wood. Usually it does not increase in diameter it decreases in its diameter. It contains water in some species, although it believed to be functionless.

\section{Wood Density}


Potential utilization of any timber species involves the consideration of wood density as it is a good indicator of strength properties and other properties of wood. Density is defined as the mass or weight per unit volume of wood.

The pooled mean of the sample trees is $0.55 \mathrm{~g} / \mathrm{cm}^{3}\left(550 \mathrm{~kg} / \mathrm{m}^{3}\right)$ which fall within the value obtained for tropical species as reported by Reyes ${ }^{15}$ and Maiti et al. ${ }^{16}$ which varied from 500 to $800 \mathrm{~kg} / \mathrm{m}^{3}$. The observed variation pattern of basic density within the tree which decreased from base to top may be due to the effect of tree age (age of cambium) ${ }^{17}$.

\section{Moisture Content}

Moisture content is the ratio of oven-dry weight of a given volume of wood to the weight of an equal volume of water ${ }^{18}$ is considered to be a good indicator of wood quality. It is one of the major factors governing the use of a plant fibre for pulp production.

The moisture content of $66.40 \%$ which is high and is also greater than $12 \%$ often reported in literature for most hardwood species ${ }^{19}$. The high moisture content could be as a result of wood anatomy, tree age and specie hence, the need to dry wood before use for efficient handling, transportation and storage.

\section{Longitudinal shrinkage}

\section{ANISOTROPIC CHARACTERISTICS OF WOOD}

Longitudinal shrinkage occurs in the direction of the growth. Longitudinal shrinkage is the defect that is most frequently associated with juvenile wood ${ }^{3}$. Apparent excessive longitudinal shrinkage is caused by cross grain, curly grain, and any other distortion of the fibers from their course parallel to the long axis of a piece of wood.

The $0.42 \%$ longitudinal shrinkage obtained in Z. mauritiana fall between $0.1 \%-1.5 \%$ and further confirmed that longitudinal shrinkage of the wood usually very small and less than one as reported by Akpan ${ }^{20}$. This shows that lumber from this specie can exhibit minimum dimensional changes after drying. This might be an advantage for the stability of the wood for structural work ${ }^{5}$.

\section{Radial shrinkage}

The radial shrinkage runs from the pith to bark direction, provides lateral support for biochemical and in many cases performs a fraction in the storage of function in wood ${ }^{12}$. The pattern of variation observed in Z. mauritiana opposed that of Sotannde and Riki, ${ }^{5}$ who reported an increased from the base to the top. The observed trends in the relationship between sampling heights might be due to the decreased wood content with height ${ }^{21}$.

\section{Tangential shrinkage}

Growth rings of tangential shrinkage appear as a series of cones, one within the other and with the apices of the cone point toward the top of the tree. The tangential planes are at right angle to the radial planes. The tangential plane of section does not provide any information about features that vary in the radial direction, but it does not provide information about the tangential dimension of feature ${ }^{12}$. Generally shrinkage along the principal direction slightly increased with increase in sampling height ${ }^{21}$.

\section{Volumetric shrinkage}

The volumetric shrinkage recorded is approximately the sum of tangential and radial shrinkage, thus confirming the negligible shrinkage in longitudinal direction, the high radial and tangential shrinkage might be due to the alignment of wood cells in those axes ${ }^{22}$.

\section{Microscopic Description of Z. mauritiana}

In Z. mauritiana wood there is a wide variety of axial parenchyma patterns in which the parenchyma cells are associated with the vessels. The fibres are diverse than those found in softwood which will have positive impact on the wood density ${ }^{23}$.

\section{CONCLUSION AND FUTURE RECOMMENDATION}

The wood of Z. mauritiana is heavy. Within and between tree, wood density decreased from the base to the top. The range of values obtained in this study fall within the range of $450-750 \mathrm{~kg} / \mathrm{m}^{3}$ for species suitable for furniture, sheeting and lining, parquet, veneer wood for peeling and slicing.

The range of values of volumetric shrinkage along the height and radial position shows that the wood is dimensionally stable. This was evident in the low tangential-radial shrinkage ratios recorded. Thus, indicating a low risk of deformation in wood during seasoning. 
The microscopic description of the wood specie shows that fibres are abundant in relation to the vessels and parenchyma cells with cell thickness that range from thick-walled to medium wall. The high density in the wood specie ocuured as a result of the abundant fibres and parenchyma cells.

This study has been conducted to provide quantitative information regarding the utilization potential of Z. mauritiana wood and to be able to compare this timber specie as possible substitute to choice over-exploited timber species in Sudanosahelian environment of Borno State, Nigeria.

It could be recommended based on the density and anisotropic properties of $\boldsymbol{Z}$. mauritiana could be used for timber and construction purposes in Nigeria.

Also, further studies should be carried out to determine the mechanical and anatomical properties of $\boldsymbol{Z}$. mauritiana wood to be able to subject it to full utilization as a small diameter timber and more sample positions should be considered.

\section{SIGNIFICANCE STATEMENT}

This study discovered some physical appearance of wood of $\boldsymbol{Z}$. mauritiana that can be beneficial as a species for timber. Also, description of the specie through microscopic examination were given with the presence of fibres and parenchyma cells. Density is strickly a function of the type of cells and the thickness of the walls. The wood is dense and fibres are usually thick-walled, the fibres are abundant in relation to the vessels and parenchyma cells.

This study will help researchers to uncover the critical areas of utilization of the wood species that many researchers were not able to explore. Thus a new theory on a lesser used species may be arrived at.

\section{ACKNOWLEDGMENT}

Authors appreciate the assistance of the entire staff of the Department of Forestry and Wildlife and Veterinary Medicine, University of Maiduguri, Nigeria.

\section{REFERENCES}

1. Winandy, J.E. 1994. Effects of long-term elevated temperature on CCA-treated Southern Pine lumber. Forest Products Journal. 44(6): 49-55.

2. Jamala, G.Y., Olubunmi, S.O., Mada, D.A. and Abraham, P. 2013. Physical and Mechanical Properties of Selected Wood Species in Tropical Rainforest Ecosystem, Ondo State, Nigeria.IOSR Journal of Agriculture and Veterinary Science (IOSR-JAVS) e-ISSN: 2319- 2380, p-ISSN: 2319-2372. Volume 5, Issue 3 (Sep. - Oct. 2013), PP 29-3.

3. Philips, E. W. J. 1941. The inclination of the fibrils in the cell wall and its relation to the compression strength of timber. Empire Forestry J. 20, 74-78.

az4. Palejkar, C. J., Palejkar, J. H., Patel, A. J. and Patel, M. A. 2012. A Plant Review on Ziziphus Mauritiana. International Journal of Universal Pharmacy and Life Sciences 2(2) 2249- 6793.

5. Sotannde, O. A. and Riki, J. T. B. (2019). Wood Quality Studies Of Some Wood Species In Sudano-Sahelian Environment Of Borno State, Nigeria. Journal of Research in Forestry, Wildlife \& Environment Vol. 11(3) 8-19pp.

6. American Society for Testing and Materials (ASTM) 1984. Standard Method for Preparation of Extractive -free Wood.

7. Sotannde, O. A., Oluyege, A. O., Adeogun, P. F. and Maina, S. B. 2010. Variation in Wood Density, Grain Orientation and Anisotropic Shrinkage of Plantation Grown Azadirachta Indica. Journal of Applied Sciences Research, 6(11): 1855-1861.

8. Eckelman, C. A. 2014. The Shrinking and Swelling of Wood and Its Effect on Furniture Purdue University • Department of Forestry \&Natural Resources • 1159 Forestry Bldg. • West Lafayette, IN 479071.

9. Quilho, T., J. Gominho and H. Pereira, 2004. Anatomical characterisation and variability of the thistle Cynara cardunculus in view of pulping potential. IAWA J., 25: 217-230.

10. Oluwadare, A. O. and Egbewole, Z. T. 2008. Wood quality studies in plantation-grown Sterculia (Sterculia setigera Del.) in the Guinea savanna, Nigeria. Research Journal of Forestry 2 (1): 22-23.

11. Sotannde A. O, Anguruwa, G. T. and Ishaya, D. 2015. Wood Quality Study of 9-Year Old Plantation Grown Khaya senegalensis in Sudano-Sahelian Environment of Borno State Nigeria. Journal of Forestry Research and Management. Vol. 12, 95-112.

12. Wiedenhoeft, A.C. and Miller, R.B. 2005. USDA, Forest Service, Forest Products Laboratory, Madison, WI. Pp 12. 13. Hoadley, R. B. 2000. Understanding Wood: A Craftsman's Guide to Wood Technology.

14. Taylor, A. M and Cooper, P. A. 2002. The effect of pre harvesting girding on selected properties of red maple and eastern larch wood fiber sci. 34(2): 212-220.

15. Reyes, G., Brown, S., Chapman, J. and Lugo, A. E. (1992) Wood Densities of Tropical Tree Species. General Technical Report SO-88. USDA Forest Service, Southern Forest Experiment Station, New Orleans.

16. Maiti, R., Rodriguez, H.G. and Kumari, A. (2016). Wood Density of Ten Native Trees and Shrubs and Its Possible Relation with a Few Wood Chemical Compositions. American Journal of Plant Sciences, 7, 1192-1197. 
http://dx.doi.org/10.4236/ajps.2016.78114.

17. Evan, P. D. 1991. The strength properties of clear wood materials forum 15; 231-244.

18. Barker, D. A., Philips, O. L., Laurance, W. F., Pitman, N. C. A., Almeida, S., Arroyo, L. and Difiore, A. 2009. Do species traits determined patterns of wood production in Amazonian forests? Biogeosciences 6: 297-307.

19. Ogunsanwo, O. Y. 2000. Effects of pulp blending and beating on selected strength properties of Pine- Gmelina hand sheets in Nigeria. Journal of Tropical Forest Resources Vol. 16 (58 - 65).

20. Akpan, M. 1999. Dimensional changes of wood in service; potential of Eribroma oblanga for interior decoration. Journal of technology and development, 7: 6-11.

21. Oyagade, A. O. and Fasulu, S. A. 2005. Physical and Mechanical Properties of Trilepisium madagascariense and Funtumia elasticawood. Journal of Tropical Forest Science 17(2): 258264.

22. Josue, J. 2004. Some wood properties of Xylia xylocarpa planted in Sabah. Sepilok Bulletin 1: 1-15.

23.Skadson, E. N. (2007). Basic Wood Anatomy and behaviour. Organocjewelry.com/woodanatomy.html. 